\title{
Globalising Cities and their Spatial New Order
}

\author{
Cumhur OLCAR ${ }^{1}$
}

\begin{abstract}
Considering the changes in the built environment and individuals' daily lives, urbanism is the most significant and essential factor that leads to diverse changes worldwide. Mindful of environmental, economic, cultural, and social changes worldwide, urban geography is a concept and has a various range of impacts on cities and thence global. Globalisation is a central driving force behind the rapid social, political, and economic changes reshaping cities. Correlated with these ideas, cities globally can be seen as a relationship between the source, production, and consumption as a triangular search cycle. As a result of the correlation to economic vitality due to free trade marketing and the development of communication and transportation, the city has become a local region. A rapidly growing population of cities and a growing amount of consumption from society living in cities is one reason why there is an increase in demand for resources worldwide. This article will explain a combination of comparative developments and reconstructions of cities involved in a new environmental, economic, multicultural, and social vision to understand the existing socio-economic patterns through convergence or divergence in the towns (cities) from developing countries.
\end{abstract}

Keywords: Globalisation, urbanization, global cities and globalising cities,

\section{Küreselleşen Şehirler ve Mekansal Yeni Düzeni}

Öz

Yapılı çevredeki ve bireylerin günlük yaşamlarındaki değişimler göz önüne alındığında, şehircilik dünya çapında çeşitli değişimlere yol açan en önemli ve temel faktördür. Dünya çapındaki çevresel, ekonomik, kültürel ve sosyal değişimleri dikkate alan kentsel coğrafya önemli bir kavramdır ve şehirler ve dolayısıyla küresel dünya üzerinde çeşitli etkileri vardır. Küreselleşme, şehirleri yeniden şekillendiren hızlı sosyal, politik ve ekonomik değişimlerin arkasındaki merkezi itici güçtür. Bu fikirlerle bağlantılı olarak, küresel şehirler kaynak, üretim ve tüketim arasındaki ilişki olarak üç ayaklı bir arama döngüsü olarak görülebilir. Serbest ticaret pazarlamasının ekonomik canlılıkla ilişkilendirilmesi, iletişim ve ulaşımın gelişmesi sonucu kent yerel bir bölge haline gelmiştir. Hızla artan şehir nüfusu ve şehirlerde yaşayan toplumdan artan miktarda tüketim, dünya çapında kaynak talebindeki artışın nedenlerinden biridir. Bu makale, gelişmekte olan ülkelerdeki kasabalarda (şehirlerde) yakınsama veya ayrılma yoluyla mevcut sosyo-ekonomik kalıpları anlamak için yeni bir çevresel, ekonomik, çok kültürlü ve sosyal vizyona dahil olan şehirlerin karşılaştırmalı gelişmeleri ve yeniden inşalarının bir kombinasyonunu açıklayacaktır.

Anahtar Kelimeler: Küreselleşme, kentleşme, küresel kentler ve küreselleşen kentler,

\footnotetext{
${ }^{1}$ Amasya University, Turkey

*ilgili Yazar/Corresponding author: cumhurolcar@gmail.com

Gönderim Tarihi / Received Date: 18.05.2020

Kabul Tarihi / Accepted Date: 03.08.2021
} 


\section{Introduction}

In classifying the impacts of urban development on developing cities, economic reordering, restructuring the global economy, globalization, shift in the labour market, and socio-economic polarization contribute to the urban crisis on cities and therefore, in inter-national regions (Fox, 2001: p. 27). Considering the destruction of city habitats among street life, community relations, and cultural experiences, socio-economic gaps does not seem to be not only because of an urban succession but also because of an extension of demand of being global and the creation of expansive urban development and distribution network of production by international companies as Olds and Young (2006: p. 395) describes that "The intention, of the nation-state increasingly multilateral organizations such as the World Bank, is to use these cities to enable the nation to 'plug' into the global economy. Such cities play a critical role in acting as the specific locales within a country where key actors and institutions analyse, represent, and associate with the global space of flows."

It is accurately said that multiple regulatory roles, residential planning and transportation links are significant factors in altering the composition of the local and regional atmosphere. In addition to this, a growing amount of waste production resulted from excessive consumption of an increasing number of individuals living in cities due to challenging commercials. It characterised the stereotype of a global society by international companies as The 'McDonaldization', common tendency to call Starbucks as coffee and perception of Nike or Adidas as sports. According to the view of Meadows (cited in Sassi, 2006: p. 13), "Current thinking is that the world is living beyond its means, using resources faster than they can regenerate and producing waste in larger amounts faster than can be assimilated naturally and without danger to the environment or humans (Meadows et al. 1992)." In conclusion, urban development causes deterioration of city balance and unutilized waste production, which are endemic in environmental perspectives and consumption in developing cities.

Due to the economic vision of urban development, resource depletion has been caused by excessive consumption of society living in cities and massive production of international companies. Therefore, increasing consumer demand from societies allows global companies to reach the remote corners of earth for new raw materials and other essantial commodities. Sassen (2006b: p. 83) argues that "Insofar as an economic analysis focused on cities and communities recovers part of the global economy though typically not marked as such - one can examine the possibility of a new politics that operates in this new transnational economic, geography, whether the actors are factory workers in export processing zones or cleaners on Wall Street." Following this point of view, there is no resolving way to hold the vicious circle of demand and supply. However, global companies maintain to provide their production units by desirous stability. Moreover, as a result of the irrepressible desires of global companies, a growing number of individuals have been obligated to migrate into cities from their hometowns, integrated global companies have already damaged. Sassen (2006b, p. 96) asserts that "Economic globalization and telecommunications have contributed to producing a spatiality for the urban which pivots on cross-border networks and territorial locations with massive concentrations of resources."

A rapidly growing population of cities and a growing amount of low and high skilled labour market in cities is one reason why there is an increase in demand for resources in developing cities. As a result of the correlation to global economic repositioning in growing cities and the development of the national economic revolution, the city has become an economic growth machine. This growth machine is directly linked to 
demographic growth, in especially cities from developing countries. Furthermore, there is another demographic research which U.N. does (cited in O'Toole, 2009: p. 99) that "As recently as 1950, less than 30 percent of the world's people lived in urban areas. By 2050, the U.N. predicts, it will be 70 percent." This study emphasizes the consequence of urban growth with relations between excessive consumption and the growing urban population or vice versa. In this light, an increasing population brings more polarized, marginalized and dissociated socio-economic and cultural patterns in cities related to emerging development projects by coalition consisted international and national élites.

\section{Globalising Cities}

In terms of developing cities, urban growth reduces land usage in the cities and shapes new global and digital space for individuals to interact with new global urban culture. Kras (1994: p. 13) explains, "It seems likely that re-urbanization, reflecting economic restructuring a policy effort to improve living, working and leisure conditions in city centres." In addition, as previously mentioned, urban consumer and increasing population of cities is the primary cause for reconstructing globally integrated cities. Smith (2001: p. 107) asserts that "On the other hand, these flows and interconnections intersect in particular places at particular times, giving each place its own unique dynamism and making it possible for us to envision a 'global' or 'progressive' sense of place." According to this view, to supply regenerated cities, understanding reconstruction can reveal and design by architects, designers, and individuals with concerns about accessing global sustainability. The result is different in developing cities as Moulaert et al. (2003, p. 1) asserts that "the outcome, then, further erodes socio-spatial cohesion and produces a new space, which includes the few and excludes the many (Moulaert et al., 2003: p. 20)." Ferguson (2006: p. 183) illustrates that "We like to imagine cities that are not subjected to planning, where people do whatever they feel is necessary: Where they create their spaces according to their own needs, reflecting their individual creative instincts." Considering the new vision for developing cities, Moulaert et al. (2003, p. 1) assert that "Cities are brooding places of imagination, creativity, innovation, and the pervasive process of physical decay and suffocation, social exclusion and marginalization, and are rife with all manner of social and political conflict, and often outright despair in the midst of the greatest affluences, abundance, and pleasure." Considering the main target of developing cities being a socalled 'global city', this aim has resulted in a highly marginalized social stratum.

The expansion of urban growth in cities has given rise to inequality. The unequal income distribution through an increasing number of high-earning individuals is one reason why there is a gap between the socio-economic reorganisation of developing cities. Another reason for enhancing inequality is that the rising cost of living reduces affordable housing and low income in the core areas of these global-city regions. As a result of the high cost of living in the central areas, most people in the city are agglomerated through the periphery, which is not associated with the global economy. Correlated with this reason, fluctuations in financial markets are directly linked to the cities from developing and developed countries. It is the fundamental reason why there is critical instability in resident's livelihoods in the global city (Logan, Taylor-Gooby, and Reuter, 1992: p. 146-149; Fainstein, 2002: p. 294; Sassen, 2006a: p. 162, 195-196). In terms of increasing marginality in society, Isin (2002: p. 350) described that "Globalisation is engendering new patterns of global differentiation in which some states, societies, and social groups are becoming increasingly enmeshed with each other while others are becoming increasingly marginalized." Rising inequality as a form of social order and as a form of conceptualizing the global city is dated from the 
globalisation period of the world. The sweeping changes caused by globalisation appeared to be replacing extreme polarization forms of social organisation with the emergence of disparity in economic position (Moulaert, 2000: 26-28; Robinson, 2006: p. 153). Fainstein (2002: p. 285) argued that "Despite being, in aggregate, the wealthiest areas of their respective nations, global city-regions tend to have large, dense groups of very poor people, often living in close juxtaposition with concentrations of the extraordinarily wealthy." As inequalities are located in the intra-regional or intraurban as an exclusion mechanism, the new strata of socio-economic and socio-cultural élites hold the front and broad view of developing city. Therefore, social polarization results from that one part of the population are experienced prosperity, and the other part has to struggle with rising deprivation, marginalisation, and disempowerment. Considering these dualities in the cities from developing countries, the composition of each one of them also encapsulate a range of disparity through the same issues. Whilst there is a rising luxury towards a small élite beyond massive consumption in cities, many other social groups are faced with struggling for survival in daily life (Amin, Massey and Thrift, 2000: p. 9; Moulaert et al., 2003: p. 4-13; McMichael, 2007: p. 220221). Moulaert et al., (2003: p. 20) noted that "The outcome, then, further erodes sociospatial cohesion and produces a new space, which includes the few and excludes the many." Both Zukin and Hamlett (cited in Moulaert et al., 2003: p. 13) argued the same issue is that "In an environment in which socio-spatial ordering by and for the market has become the dogma of the day, urban regions have become, more than ever before, landscapes of power (Zukin 1991) where islands of extreme wealth and social power are interspersed with places of deprivation, exclusion, and decline (Hamlett 1996)."

The development of a new economy towards other globalisation approaches seems likely that recycling elements of the élite coalition to handover of power, opportunity, and prosperity to its next generations. The result is distinct that unemployment. Moulaert et al. (2003: p. 1) asserts, "Many urban communities were left in the doldrums of persistent decline and permanent upheaval and are still faced with the existential disorientation that comes with lasting unemployment." While both employment and acquisition of skills are restricted not democratically but socially, it can be available to continue in this way, particularly in developing cities depends on relevant connectivity and social networks. Lawless (cited in Moulaert et al., 2003: p. 31) noted, "The transformation of employment is, doubtless, the key axis of urban socio-economic restructuring and the primary factor shaping increasing inequality and social fragmentation in cities." However, as Moulaert et al., (2003: p. 31) noted "But unemployment is only the tip of an iceberg of increasing the casualization of labour markets that involves increasing segmentation, skill polarization, flexibility, and externalization." Without the influence economic conditions, there are permanent and seem not to be able to resolve issues in the global city, including high levels of unemployment, temporary and periodic employment, homelessness, deteriorating housing and living conditions, widening income gaps, and social violence, etc (Amin, Massey and Thrift, 2000: p. 33; Moulaert et al., 2003: p. 30). In terms of professionalism, as mentioned above, Sassen (2002b: p. 83) asserts that "A hypothesis is that the growing numbers of high-level professionals and high-profitmaking specialised service firms have the effect of raising the degree of spatial and socioeconomic inequality evident in these cities." As a result of unemployment, income loss, or wage cuts, the lack of purchasing power results in excluding individuals from contribution and consumption. A provision of highly skilled employment from globalised sectors is becoming increasingly less attainable for major cities. This also resulted in obstruction for further social protection and pensionary provisions and emerging new types of urban poor with inextricably complicated socio-cultural identity (Moulaert et al., 
2003: p. 49-51; McMichael, 2007: p. 226). Within the new global economic structure rooted in the developing city, social polarization is to be required by leading globalised sectors towards employ groups demarcated by high-income and highly skilled workers adverse low-paid and low-skilled workers (Logan, Taylor-Gooby, and Reuter, 1992: p. 146-149; Samers, 2006: p. 386; Sassen, 2006b: p.86). Fainstein (2002: p. 286) asserts that "Global-city theory implies that such cities will have similar social characteristics, despite differing culture, history, governmental institutions, or public policy." In this context, as a result of more active and effective economic and social contribution through progressing woman rights towards democratic approaches, the global domestic family sphere is gained much more earnings with the contribution of women and this reorganised family structure is a more common phenomenon in developing cities (Amin, Massey and Thrift, 2000: p. 21; Sassen, 2006a: p. 178-179). Fainstein (2002: p. 291) noted "The growth in income of high-end households, as well as arising from individual earnings and equity market gains, reflects the existence of families or housemates with two high-earning individuals." Nevertheless, the new contribution in family and city is generally related to the community in which part of the global city leading groups instead of the struggling majority. There is also the same contribution in this majority but not considerable yet to afford to consumption-lead networks of the global city. This distinction of contribution also reflected another inequality in the composition of urban space towards reorganised land rents and housing prices. This reorganisation is also reinforced by urban socio-economic change through emerging of excluded populations in certain parts of global city-regions. By the same time token, to ignore the social division, the global city-region confronts spatial segregation (Moulaert et al., 2003: p. 32). Mindful of economic, social, spatial, and cultural changes global citywide, citizenship is a concept and also a fact has a diverse range of impacts on cities. Related to this, citizenship of global city-regions reflects inequality in empowerment, social exclusion, and rising marginalization through increasing immigrants and migrants. There is an increasing demand from these excluded and marginalised communities to be part of democratic participation and representation (Isin, 2002; Scott, 2002; Waldinger, 2002). Scott (2002: p. 6) asserts that "Concomitantly, the nature of citizenship itself is currently being subject to much fresh scrutiny, and in some parts of the world, practical attempts are actually under way to extend the franchise not just to those who are nationals of the central state, but also to those who, whatever their nationality by birth right, have made a long-term commitment to life in the local community."

\section{Spatial Order of Global Cities}

Cities are in a constant process of internal change. The forms or functions of cities are changing as the centre of the city decline. "New business districts spring up; immigrants cluster together and mix with others; ethnic and racial groups are segregated in ghettos and slums, or they escape to more liveable neighbourhoods; new cultural enclaves are formed, while old ones disappear; new forms of cities are created at the edges of metropolitan areas; suburbanization never seems to end. Spatial divisions of themselves are nothing new, but they are not stable in their causes, in their appearance, in their scale, or their effects (Marcuse, 2000: p. 1)." After the 2000s, spatial divisions visibly develop in cities. The descriptive account of these changes multiplied. So have accounts of changes in the national and international context that parallel and perhaps cause them: a process of globalization, changing forms of production, a declining state provision of welfare, differences in power relationships, developing technologies, all have their influence on urban patterns, within cities as well as among them (Marcuse, 2000: p. 1). 
There is a new spatial order of cities, commencing somewhere in the 2000s, often described as a globalizing economy. While cities have always been divided along the lines of function, structure, culture, and status, today's pattern is new, and in many ways deeper-going, the combination of these divisions. "Although it varies substantially from city to city by the historical development of the built form, by national political and economic structures, by the relative weight of the contending forces involved in the development, by the role of 'race' and ethnicity, and by the place in the international economy, nevertheless there are basic features in common (Marcuse, 2000: p. 3)." They include a spatial concentration within cities of new urban poverty on the one hand, and of specialized 'high-level' internationally connected business activities on the other, with increasing spatial divisions not only between each of them but also among segments of the 'middle class' in between. The boundaries of divisions in the city increase between social and physical walls. The result is a pattern of separate residential spaces clusters, creating protective citadels and enclaves on the one side and constraining ghettos on the other, in a hierarchical relationship to each other. The market produces and reproduces these divisions, but cities are deeply involved in their creation and perpetuation. Current trends do not show it will happen so in most places. The result is a converging pattern within cities radically different enough from earlier patterns to justify being called a new spatial order (Amen et al., 2006: p. 3).

In some countries and especially in some cities, the states that claim to be welfare states reach out to the poor and deprived citizens either very limited or very ineffective. Especially since World War II, the main principles of the welfare state have always been twofold: an elaborate system to support those who are in a weak position on the labour market and the existence of a system of subsidies in all kinds of fields, like housing, recreation, and social work. Significantly since the middle of the 2000s, the welfare activities of states have been declining or retreating. Declining incentive and support stimulus is a threat to the housing market, which must be formed in a variety that is affordable for every citizen. "Declining incomes directly influence the housing market opportunities of households because they are relegated to those dwellings they can afford to pay. When these dwellings are spatially concentrated in certain areas of the cities, increased spatial divisions may result, characterized by an increasing concentration of relatively poor households in areas with low-rent (and often lowquality) dwellings and growing segregation different income groups. Thus, spatial divisions become sharper as public sector policies lead to an increasing polarization of incomes (Marcuse, 2000: p. 9)." Of course, the collapse of the welfare state does not lead to increased concentration and segregation alone. In other words, local governments observed that local governments develop specific neighbourhoods in different forms and functions compared to others with the zoning plans and license approvals. Instead of the policies that should be produced for a more affordable housing market, municipalities are far from making policies that aim to ensure that lowincome families own property with a post-capitalist and neo-liberal urbanism approach. The municipality setting policies for the housing market will be the living space of citizens with high financial opportunities and accumulation. And in specific locations where social housing has been a factor in increasing segregation, it leads to a net worsening of the housing situation of the poor, as may be the result of current privatisation policies in public housing in the globalising cities (Acuto, 2013: p. 10).

Since wealthy and elite families lived in the city since the 2000s, they separated their living spaces from the regions where the other families lived. Mansions or high-rises with penthouses turned the residential areas where the rich live with privileged luxury service into defined and isolated islands in the city. They might cluster in neighbourhoods, but their neighbourhoods were not defined and isolated for protection 
as such. That pattern continues, but in addition, a newer design seems to be developing, the citadel. "Citadels are enclosed, protected, insulated areas of upperincome residence, often, particularly if located downtown, combined with office and commercial uses. Citadel formation is in some ways an extension of prior (and continuing) gentrification, but goes well beyond it. Gentrification by and large took place at the borders of the old downtowns, and was of the hard-working professionals, managers, a technical person associated with the growing upper-income service sector (Marcuse, 2000: p. 13)."

Gentrified neighbourhoods and areas of potential gentrification near downtowns are particularly affected by the changing productive structure of the economy. The gentrified city is the part occupied by the professionals, the managers, and the higher technicians. Gentrification is by the same token likely to increase the displacement of the poor from gentrified areas, for the regions of gentrification generally consist of older buildings, left vacant by poorer households after a process of displacement and rising prices. The municipalities promoting housing expansion as a result of local policies do sometimes gentrification. Improvement strategies may precede it to increase the appeal of inner-city living for the new middle class. This could be in the form of attractive housing, and offer new places of entertainment, including concert halls, theatres, or shopping malls. Parts of the central business district and lands in harbour areas or former industrial sites also develop as a gentrification area for wealthy families and individual professionals (Passotti, 2020: p. 14).

The typical picture includes owner-occupied single-family houses with decent homeowning people, gardens, green environments, and liveable places for children to play, quiet, and safe. The residential function is far more important than anything else. It is quite the same for every global city but globalising towns offer something different. In globalising cities, there are suburbs but with housing block rather than single-family houses. Suburbs are generally the living areas of families with middle income. Suburbs are preferred areas for families with income to buy apartments in residences with an aesthetic appearance with green spaces, albeit limited in the city. For some, a suburban location may be a place to live only as long as the children are in the house. They may consider moving (back) to the city after that; they are potential gentrifiers. In general, suburbs do not show many changes in their population structure, both because mobility rates are relatively low and because vacancies in the housing stock are generally filled by people of the same lifestyle and income. The only change then is the age structure. "Suburbs do not include those with controlling positions in trade, industry, or finance. Their centres remain in or close to the central business districts. Neither do the new cities include the very poor. Their residents are indistinguishable from those of the typical suburb (Marcuse, 2000: p. 15)." It is clear that edge cities compete with the existing towns: the central city no longer is the dominant site in the metropolis for jobs, offices, restaurants, shops and cinemas. In addition to suburbs and edge cities, there is another region in the cities, namely the urban island. As seen in every city, this region is indispensable for globalizing cities. The tenement city is a traditionally working-class area. The blue- and white-collar working class, the unemployed, and those on benefits occupy it. The tenement city is the part of the city with less expensive private dwellings and social housing.

In some cases, tenement areas are simply transitional residence on the way up, particularly for the young. For other people, it will be relegated to live there for the rest of their lives. Social and economic change is likely to be the most enduring characteristic of these areas, moving from an autochthonous homogenous character to either ethnic mixture of ethnic concentration (Clark, 2016). 
Dwellings dating from the first half of the 20th century as pre-global tenement areas can often be regarded as the worst part of the urban housing stock. Housing stock had usually small, lacking basic facilities, like a bathroom; rents were generally relatively low. A mixture of housing types characterizes them. Occupants of these housing types were people with low incomes including the unemployed, students, immigrants, elderly, single-parent families. The enormous differentiation in lifestyles between these categories caused tension, racial problems, social isolation, and fear to go outside at night. Partial or complete gentrification was an increasing phenomenon in such areas. A special kind of dual city can be seen in contrasts in social status and wealth in spatial proximity creating segregation and otherness. A dual city is where the poor and rich live together in the same areas, but use very different spaces: the rich go to the streets with the luxury shops, the poor visit the street bazaars; the rich use private cars, the poor public transport; and they have different places of work. Early post-global tenement areas contain many affordable social rented housing, built to cope with the enormous housing shortages resulting from the financial crisis. City managements was aimed at housing middle-class families of moderate income at that time. Since they were built some developments have changed the areas from attractive family neighbourhoods to areas where many people do not want to live. New housing areas with more attractive housing have pulled households who could afford to move and to pay higher prices for their dwellings out of these areas. The future of these areas, directly affected by changing demographics and the ebb and flow of immigration, is mainly dependent on government action. Without any intervention they will end up as the neighbourhoods where only those without any other choice will end.

On the other hand, the intervention that includes demolishing or upgrading part of the existing stock may attract those middle-class households for which the areas were initially built. High-rise areas typically date from the period 1980-present. They were created because the post-expansion of urbanization housing shortage continued and it had now become technically possible to build high-rise structures relatively cheaply. In many cities high-rise areas initially housed middle-class families, and in many cities they still have this function. Ethnic enclaves can often be seen as the specific type of working-class areas. An ethnic enclave should be clearly distinguished from ghettos: the dominant interests of society desired to the confinement of the ghetto's residents (Marcuse, 2000: p. 16-8).

The pattern of changing land uses within the urban landscape is a centuries-old pattern. Before the financial period of capitalism, slum formation took place in areas of traditional residence for poor people and in higher-income neighbourhoods whose location became increasingly undesirable for those who could afford better. Hitherto, however, new uses replaced the older ones. New populations moved in where earlier ones moved out. Especially in the globalising cities entire parts of cities have been abandoned by the owners of their properties and by their residents, and then by their governments. The excluded ghetto is prototypical, of the extreme, form of the abandoned city. These sections have the town that viewed from the outside, only a negative relationship to the rest's social, political, and economic life. It has its structure and organization, its economy, largely informal and formal. Indeed some of its residents are regularly connected to the rest of the city's economy and social and political life (Duneiier, 2016). 


\section{Invisible Characters of Globalising Cities}

"Structural economic and political change produces both extreme wealth and extreme poverty, concentrated power and concentrated powerlessness, ghettoization and citadelization, and not by accident: the decrease at the one end is in large part the result of the increase at the other (Marcuse, 2000: p. 251)." The social relationship that develops in homogenization with its socio-economic community and isolation with different communities is physically and economically observed every quarter. Thus, the changing spatial order of cities suggests two characteristics: divisions between quarters, with each quarter more and more isolated from its surroundings, and a totalizing trend, in which each quarter more and more depended on its socio-economic structure within its boundaries all of the necessities of life. However, each characteristic shows trends that manifest well before, globalization and is represented in cities in various relationships to globalization (Pooch, 2016).

In high-tech, generally high-rise megaprojects, Citadels are becoming prevalent throughout the world, from Shanghai to Kuala Lumpur. The architectural style remains global. It was dubbed the international style already in the twenty century, but has earned that name now. Fashions in styles may vary, but the presence of power, wealth, of luxury is inherent, as is the isolation, the separation, and the distancing from the older urban surroundings. However, the use of the citadels is not confined to those living in the luxury city; managers, professionals, technicians, and administrators to carry out the functions assigned to them are indispensable. Residentially, not many may walk to work there from the gentrified city, the city of the gentry, if it has a lodgement nearby; some may use luxury boats in seaside towns or may fly in by flycar including helicopter to land on the roof landing pads that characterize, for instance, almost every office building in Bernini, in Sâo Paulo. Still, most will commute in by some form of limited transportation access, likely to be not affordable but publicly subsidized, and likely to permit access even from a distance without treading on the ground of the rest of the more mundane city. Globalization functionally has produced a class of professionals, managers, technicians, that may well be seen to the gentry of earlier days in feudal systems.

As there is an increase in numbers, so global gentry do increase in importance and income. Therefore the residential locations of global gentry become ever more identified and separated (Marcuse, 2000: p. 252). "The gentrified city is often located in the inner parts of the older cities, or in neighbourhoods adjacent to this part. The attractiveness of areas close to the inner cities, the places where urban activity is centred, is particularly attractive to the gentry; and because these are often areas formerly occupied by the working class, the link between gentrification and displacement is close. The relationship between gentrified areas and citadels requires further detailed investigation. There is probably a separation between those truly in control and those who work for them in each urban area, even at high levels within organizational structures. The separation is probably visible in the size and location of second homes, but very likely of first homes also. The top of the hierarchy is not likely to be involved in the process of gentrification, although, after a neighbourhood has been converted, units within it may serve them as pieds-a-terre (Marcuse, 2000: p. 254)." Exclusionary enclaves are not new in the globalising cities, but their spread has been phenomenal in the last several decades. The gated communities, the walled communities of the rich, now more isolated from the rest of society than ever before, are now found, in the global cities and Johannesburg, Rio de Janerio many other globalising towns worldwide. The residents live in walled communities, not spatially dependent on any particular geographical location about the rest of the city. They 
instead create and control their environment at the micro-level. The global gentry has defined a socio-spatial pattern to isolate themselves from the rest of the city through walling and gating. However, being gentrified areas suggests erecting walls to define their boundaries since they are encroachments on and reuse valuable parts of the city previously occupied by poorer residents. Hence forth, the exclusion and control are accomplished by social and cultural, rather than being more physical (Marcuse, 2000: p. 253-5).

Public spaces have similarly experienced a significant change, in form, usage, and control. The general movement is towards private control of what is done in public spaces. Sometimes, private control is exercised through pressure on public authorities, as in the tidying up of squares or amusement districts in cities; sometimes it is done directly privately, as in the use of private security guards by Business Improvement Districts or the managers of gated communities. Sometimes, ironically, the privatization of public space develops through semi-public facilities is legally private spaces, including malls and shopping centres. The pure result is the same: the amount and openness of space for public activities become ground down or deteriorate. Touristic spaces are increasingly prominent as the object of public attention and private investment, producing spatial changes in many globalising cities. Thus a familiar pattern of change in comparable locations is visible. However, it does not rise to the scale of a new structural spatial order, because it primarily represents a continuation of pre-existing trends (Chia-ho and Tsu-lung, 2015).

\section{Conclusion}

In conclusion, cities from developing countries can be seen as the first and latest focusing point to define globalisation and its impacts. Cities have shaped the relationship between human beings' economic, environmental, social, and cultural components. Meanwhile, with benefits from technological and industrial innovations and developments, urban boundaries have not limited perceptions and facts. The forced migration of a massive rural population worldwide is an extension of urban growth's environmental and economic background. To increase interconnected relations between a range of local and national cultures and traditions, and popular culture with social distinctions could be seen forefront of urban growth which reflect and regenerate cities accurately from developing countries. According to these views of urban growth are relevant to how that requires the patterns in each particular dimension in socio-economic structure to reconstruct cities located local parcels but globalised land in developing countries.

Thus globalization, significant as it is, is only one of the forces determining the spatial pattern of cities, and a force not coming into the scene for the first time in the twenty century. It should be seen as the extension of forces already present over a much more extended period. The globalising city is a term that has become phenomena as a way to describe cities at the place just after the apex of a postulated global hierarchy of cities. These cities determined primarily by their role as locations of the control functions of international finance. Globalising cities are very different from each other in their spatial configurations. While they have trends in common, they have significant differences, and do not lend themselves to the built of some generally applicable global city model. Thus, globalizing cities is the term to reflect two different factors: that the process of globalisation influences all cities and that participation in that process is not a matter of being either at the top or the bottom of it, but rather of the nature and extent of influence of the process. 


\section{References}

Acuto, M. (2013) Global Cities, Governance and Diplomacy: The Urban Link. Oxon: Routledge.

Amen, M., Archer, K., and Bosman, M. (2006) Relocating Global Cities: From the Center to the Margins. Oxford: Routledge.

Amin, A., Massey, D, and Thrift, N. (2000) Cities for the Many not to Few. Bristol: The Policy Press.

Chia-ho, S. and Tsu-lung, C. (2015) Arts, Culture and the Making of Global Cities: Creating New Urban Landscapes in Asia. Chelthenam: Edward Elgar.

Clark, G. (2016) Global Cities: A Short History. Washington, D. C.: The Brookings Institution.

Duneier, M. (2016) Ghetto: The Invention of a Place, the History of an Idea. New York: Farrar, Straus and Giroux.

Fainstein, S. S. (2002) 'Inequality in Global City-Regions', in Scott, A. J. (ed.) Global City-Region: Trends, Theory, Policy. Oxford: Oxford University Press, 285-299.

Ferguson, F. (2006) Talking Cities: The Micropolitics of Urban Space, Essen, Germany: Birkhauser-Publishers for Architecture.

Fox, J. (2001) Chomsky and Globalisation. MyiLibrary [Online]. Available at: http://0lib.myilibrary.com.emu.Iondonmet.ac.uk (Accessed: 12 January 2012).

Isin, F. E. (2002) 'Istanbul's Conflicting Paths to Citizenship: Islamisation and Globalisation', in Scott, A. J. (ed.) Global City-Region: Trends, Theory, Policy. Oxford: Oxford University Press, pp. 349-371.

Kras, R. (1994) Industrial Design in the Urban Landscape?, Amsterdam, The Netherlands: De Balie.

Logan, J., Taylor-Gooby, P. and Reuter, M. (1992) 'Poverty and Income Inequality', in Fainstein, S. S., Gordon, I. and Harloe, M. (ed.) Divided Cities. Cambridge: Blackwell Publishers, pp. 129-151.

Marcuse, P. (2000) Globalising Cities: A New Spatial Order? Oxford: Blackwell Publishing.

McMichael, P. ( 2007) 'Globalisation: Myths and Realities', in Roberts, J. T. and Hite, A. B. (ed.) The Globalisation and Development Reader. Malden: Blackwell Publishing, pp. 216-233.

Moulaert, F. (2000) Globalisation and Integrated Development in European Cities. Oxford: Oxford University Press.

Moulaert, F., Rodriguez, A. and Swyngedouw, E. (ed.) (2003) The Globalized City: Economic Restructuring and Social Polarization in European Cities. Oxford: Oxford University Press. 
Olds, K. and Yeung, H. W. (2006) in Brenner, N. and Keil, R. (ed.) The Global Cities Reader. London; New York: Routledge Publications, pp. 392-400.

Pooch, M. (2016) DiverCity - Global Cities as a Literary Phenomenon. Bielefeld: Majuskel Medienproduktion.

Robinson, J. (2006) Ordinary Cities: Between Modernity and Development. London: Routledge Publications.

Samers, M. (2006) 'Immigration and the Global City Hypothesis: Towards an Alternative Research Agenda', in Brenner, N. and Keil, R. (ed.) The Global Cities Reader. London; New York: Routledge Publications, pp. 384-391.

Sassen, S. (2002) 'Global Cities and Global City-Regions: A Comparison', in Scott, A. J. (ed.) Global City-Region: Trends, Theory, Policy. Oxford: Oxford University Press, pp. 78-96.

Sassen, S. (2006a) Cities in a World Economy. London: Pine Forge Press.

Sassen, S. (2006b) 'Cities and Communities in the Global Economy', in Brenner, N. and Keil, R. (ed.) The Global Cities Reader. London; New York: Routledge Publications, pp. 82-89.

Sassi, P. (2006) Strategies for Sustainable Architecture, New York: Taylor \& Francis. Scott, A. J. (ed) (2002) Global City-Region: Trends, Theory, Policy. Oxford: Oxford University Press.

Smith, M. P. (2001) Transnational Urbanism: Locating Globalisation, Massachusetts, USA: Blackwell Publishers.

Waldinger, R. (2002) 'The Immigrant Niche in Global City-Regions. Concept, Patterns, Controversy', in Scott, A. J. (ed.) Global City-Region: Trends, Theory, Policy. Oxford: Oxford University Press, pp. 299-325. 